\title{
Rate and course of atresia during follicular development in the adult cyclic rat
}

\author{
P. Osman \\ Department of Anatomy, Medical Faculty, Erasmus University, P.O. Box 1738, \\ 3000 DR Rotterdam, The Netherlands
}

\begin{abstract}
Summary. Ovarian follicles ( $\geqslant 100 \times 10^{5} \mu \mathrm{m}^{3}$ or a mean diameter of $\geqslant 275 \mu \mathrm{m}$ ) in adult rats were classified as non-atretic and atretic during the oestrous cycle and recorded in 5 volume classes. The atretic follicles were also categorized in several stages according to the progress of atresia. The degeneration of the entire granulosa wall until the induced changes in the oocyte took at least $24 \mathrm{~h}$. Another $24 \mathrm{~h}$ elapsed before the oocyte became denuded. Therefore the $\%$ of atretic follicles, i.e. follicles in all stages of atresia, could not be used as indicator for the rate of atresia. The atretic portion in the follicle population $\geqslant 100 \times 10^{5} \mu \mathrm{m}^{3}$ increased from early dioestrus 1 to early dioestrus 3 , reached a plateau during dioestrus 3 and pro-oestrus, and declined at late oestrus to the level of early dioestrus 1 . The sudden decrease in number of atretic follicles after late pro-oestrus was caused by the discard of many atretic follicles in the advanced stages due to various deformities as revealed by histological observation. By using the \% of atretic follicles in the earliest stage as indicator of atretic rate, two waves of atresia were found affecting the population of antral follicles during their growth, the first at dioestrus 1 amounting to $15-20 \%$ and then at dioestrus 3 , affecting $35 \%$ of the population. The present study also shows the extension of atresia in the various volume classes of follicles during the oestrous cycle. A pool of $\sim 7$ follicles in the smallest volume class was maintained after ovulation, grew further in the next cycle with a new cohort of 20 follicles, and seemed to provide the required number of follicles destined to ovulate. This suggests that the follicles that ovulate were already present at an antral stage in the preceding cycle and needed two cycles for their growth to ovulation.
\end{abstract}

\section{Introduction}

Although follicular atresia is a prominent feature in all mammalian ovaries, this phenomenon is still not well understood. It is widely held that waves of atresia affect the number of follicles in phase with the oestrous cycle (Lane \& Davis, 1939; Boling, Blandau, Soderwall \& Young, 1941). Atresia is often assumed to take place from the steady decrease in number of healthy follicles. However, neither this decrease, nor the accumulation of numbers of atretic follicles, has been demonstrated. In the rat, Mandl \& Zuckerman $(1950,1952)$ found atresia most marked in follicles of $250-349 \mu \mathrm{m}$ in diameter between the onset of oestrus and ovulation and Burkl \& Kellner (1956) found the highest frequency of atresia in follicles with a maturation spindle at oestrus. Hirshfield \& Midgley (1978), however, found atresia most marked in follicles of $200-400 \mu \mathrm{m}$ in diameter in all ovaries.

Recording all atretic follicles, including those in advanced stages of atresia, does not provide information about the time of onset of atresia since considerable time could have elapsed before the affected follicles showed signs of the advanced stages of atresia such as pseudo-maturation spindle or fragmentation of the oocyte. Moreover, the time involved for the complete disintegration of a follicle which has been affected by atresia is still not known due to several problems as stated by 
Byskov (1978). By using $\left[{ }^{3} \mathrm{H}\right]$ thymidine labelling, Byskov (1974) showed that in the mouse it takes about 3-4 days for a healthy follicle to reach an advanced stage of atresia. Many models for follicular atresia have been introduced (Braw \& Tsafriri, 1980a; Terranova, 1980; Uilenbroek, Woutersen \& van der Schoot, 1980; Bill \& Greenwald, 1981) but these relate to preovulatory follicles which normally ovulate and not to those antral follicles that are destined to degenerate. The purpose of the present study was to obtain more information about the rate and course of atresia in such follicles and the time required for a follicle in an early stage of atresia to reach an advanced stage.

\section{Materials and Methods}

Adult rats of the R-Amsterdam strain, a Wistar substrain, 2-3 months of age and weighing $170-220 \mathrm{~g}$, were used. They were kept in a temperature-controlled room $\left(22-24^{\circ} \mathrm{C}\right)$ under controlled light conditions: $14 \mathrm{~h}$ light and $10 \mathrm{~h}$ darkness with the middle of the light period at $12: 00 \mathrm{~h}$. The rats received standard dry pellets and tap water ad libitum. Vaginal smears were taken daily at $10: 00 \mathrm{~h}$. The first day after oestrus when there was an influx of leucocytes in the vaginal smear was designated as dioestrus 1 . Only animals displaying at least two consecutive 5-day cycles were used.

Groups of 5-7 animals were killed on each day of the cycle, at 10:00 h and at $17: 00 \mathrm{~h}$, with an overdose of ether. The ovaries were dissected out, fixed in Bouin's fluid and embedded in paraffin wax after routine histological procedures. Serial sections of $10 \mu \mathrm{m}$ thickness were stained with haematoxylin and eosin. In one ovary of each animal follicles were measured in the section containing the oocyte nucleolus. In large preovulatory follicles resuming meiosis after the gonadotrophin surge and in atretic follicles with a pseudo-maturation spindle or oocyte fragmentation, the diameters were assessed in the section containing the largest cross-section of the oocyte. Two perpendicular diameters were recorded using a Leitz-A.S.M. Semi-automatic image analysis system and the mean was used as third diameter for calculating the follicular volume as described by Welschen (1973). All follicles $\geqslant 100 \times 10^{5} \mu \mathrm{m}^{3}$, corresponding to a mean diameter of $\geqslant 275 \mu \mathrm{m}$, were counted, screened for atresia and classified in several volume classes: Class $1\left(100-199 \times 10^{5} \mu \mathrm{m}^{3}\right)$ corresponds to a mean diameter of $275-350 \mu \mathrm{m}$; Class $2\left(200-349 \times 10^{5} \mu \mathrm{m}^{3}\right)$ to $351-400 \mu \mathrm{m}$; Class $3\left(350-499 \times 10^{5} \mu \mathrm{m}^{3}\right)$ to $401-450 \mu \mathrm{m}$; Class $4\left(500-999 \times 10^{5} \mu \mathrm{m}^{3}\right)$ to $451-575 \mu \mathrm{m}$; and Class $5\left(\geqslant 1000 \times 10^{5} \mu \mathrm{m}^{3}\right)$ to $\geqslant 576 \mu \mathrm{m}$. Only follicles in these volume classes were used because

\section{PLATE 1}

Fig. 1. Non-atretic antral follicle of volume Class $3 . \times 90$.

Fig. 2. A Class 3 follicle in the initial stage of atresia, Ia. Note the general shrinkage of the granulosa wall. $\times 90$.

Fig. 3. Enlarged part of the granulosa wall, opposite the oocyte, of the follicle in Fig. 2. Note the pycnotic nuclei and nuclear particles between the shrunken granulosa cells (arrows). $\times 215$.

Fig. 4. Atretic follicle in Stage Ib. Nuclear particles are seen everywhere in the periphery of the antrum. The oocyte is still in the germinal vesicle stage. $\times 90$.

Fig. 5. Atretic follicle in Stage Ila. The oocyte has expelled a polar body. The shrunken cumulus cells still form an envelope around the oocyte. $\times 90$.

Fig. 6. Another type of atretic follicle in Stage IIa. The disintegrating cumulus cells are still surrounding the oocyte which is in the chromatin mass stage. $\times 90$. 
PLATE 1
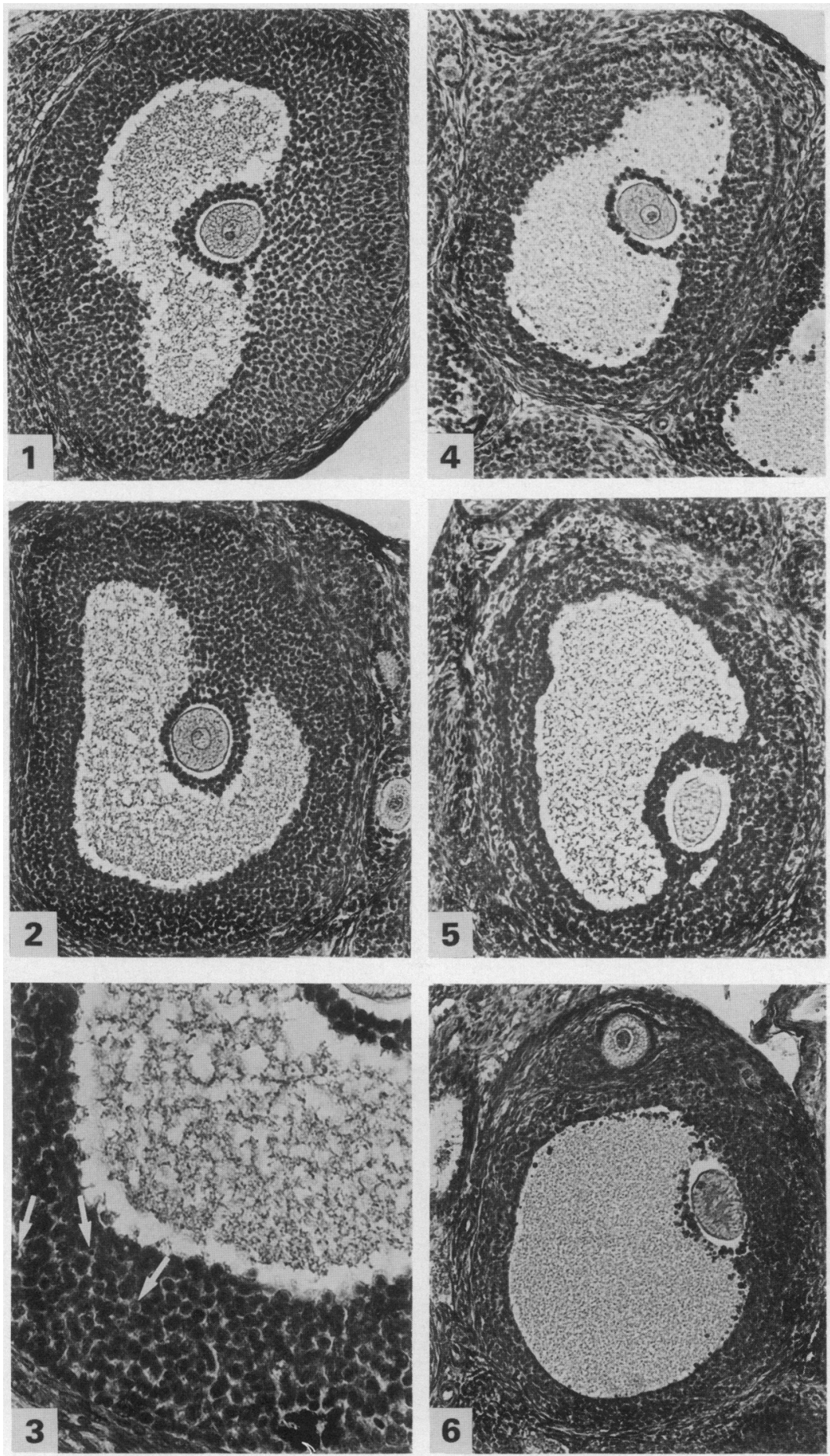

(Facing p. 262) 
PLATE 2
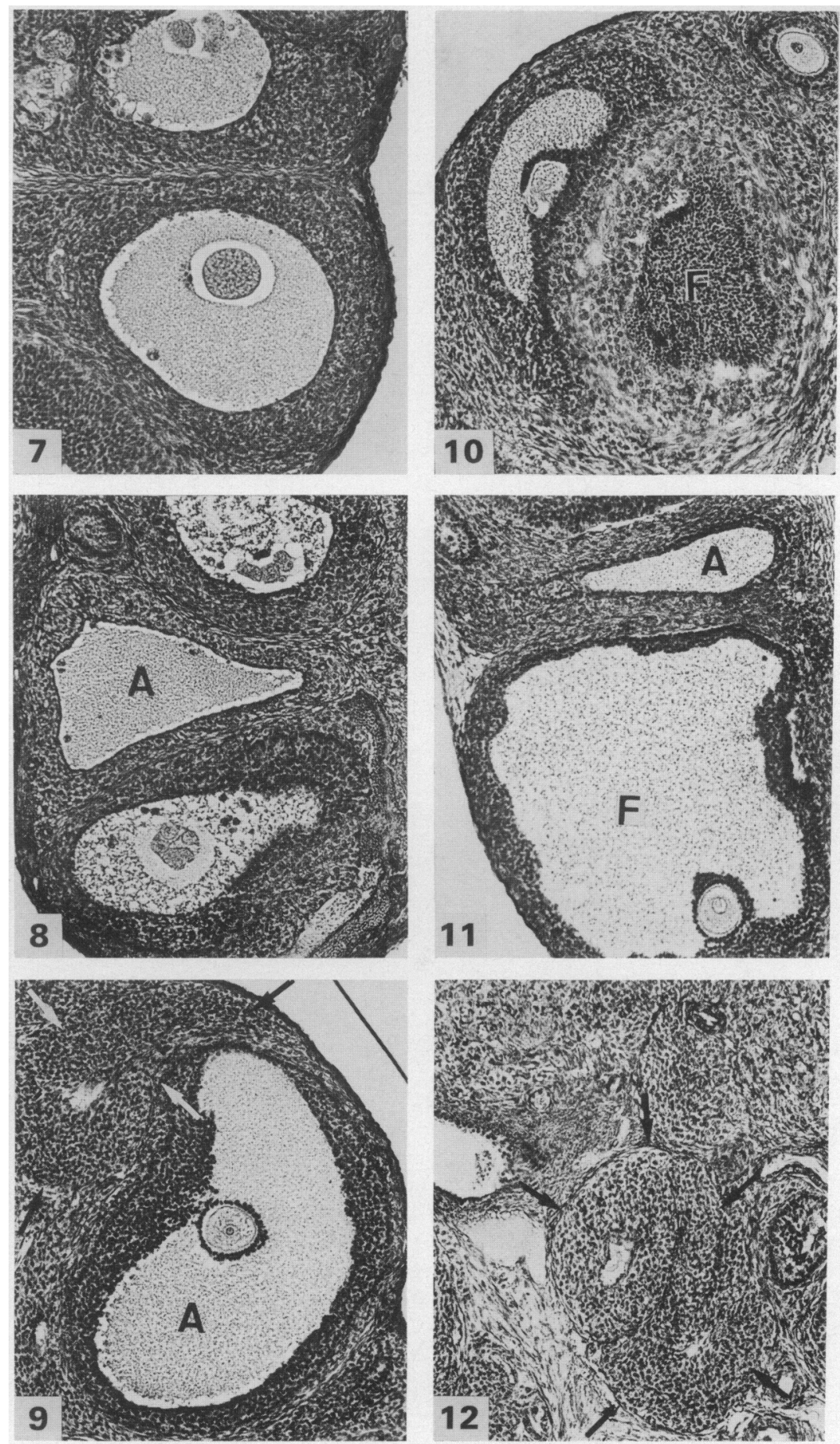
they (1) were mostly antral follicles that had entered the growth phase and were presumably therefore participating in the hormonal interactions between the gonads and pituitary (Hirshfield, 1983), (2) are easy to recognize and (3) show the highest rate of atresia (Byskov, 1978). Based on the light-microscopical observation that the first morphological signs of atresia are seen in the membrana granulosa (Deane, 1952; Braw \& Tsafriri, 1980a; Braw, Bar-Ami \& Tsafriri, 1981; Numazawa \& Kawashima, 1982) earlier than in the oocyte (Gondos, 1982), two stages of atresia were identified. In Stage I, degenerative changes are present only in the granulosa wall which shows cell shrinkage, pycnosis and karyorrhexis (P1. 1, Figs $2 \& 3$ ). At this stage the follicles are still spherical or ovoid. In Stage II, changes are also present in the oocyte which shows signs of resumption of meiosis, such as breakdown of the nuclear membrane with or without formation of a pseudo-maturation spindle, and oocyte fragmentation. In antral follicles the oocytes are able to resume meiosis spontaneously after the granulosa cells degenerate (Foote $\&$ Thibault, 1969). At this stage most follicles show deformities (Pl. 2, Figs 8 \& 10).

Follicles in Stage I can be further subdivided into Stage Ia, in which overall shrinkage of the granulosa wall is apparent at a low magnification and detailed degenerative changes are seen at higher magnification in scattered small areas ( $\mathrm{Pl}$. 1, Figs $2 \& 3$ ), and into Stage Ib, in which the whole granulosa wall is affected by degeneration. At this stage many nuclear fragments are seen at the periphery of the antrum (Pl. 1, Fig. 4). Stage II follicles can also be subdivided into Stage IIa, in which the degenerating oocyte is still surrounded by an envelope of degenerating cumulus cells or their remnants (Pl. 1, Figs $5 \& 6$ ), and Stage IIb, in which the oocyte is found 'naked' in the antrum. At this stage the granulosa wall usually has a distinct inner lining. No or only few nuclear particles are seen in the antrum, but macrophages are usually present (P1. 2, Fig. 7).

Values are given as mean \pm s.d. Analysis of variance (Winer, 1971) and the Wilcoxon twosample test were used for statistical analysis of the results. A difference was considered significant if $P \leqslant 0.05$.

\section{PLATE 2}

Fig. 7. Two atretic follicles in Stage IIb. Note the naked oocyte. In the lower, Class 1 follicle, a few macrophages are present near the oocyte and at the periphery of the antrum which shows a distinct lining. In the smaller upper follicle $\left(<100 \times 10^{5} \mu \mathrm{m}^{3}\right)$ the oocyte has become fragmented. Many macrophages are seen at the periphery of the antrum. $\times 73$.

Fig. 8. A triangle-shaped section of an old atretic follicle (A), not measured, since the oocyte has completely disappeared. The granulosa wall has also disappeared and macrophages can be seen in what was the antrum. The thecal layer is thickened. The atretic follicle seems to be partly compressed by two neighbouring follicles which have become atretic themselves and are in Stage IIb. $\times 73$.

Fig. 9. A comma-shaped section of an old atretic follicle of which the thickened thecal wall is left (arrows) with a small remnant of an antrum. This follicle has been compressed by the growing antral follicle $\mathrm{A}$, which is in Stage $\mathrm{Ib}$ of atresia. $\times 73$.

Fig. 10. A section of an atretic follicle in Stage IIa, deformed by a growing preovulatory follicle (F) tangentially cut through the granulosa wall. $\times 73$.

Fig. 11. Section of a follicle (A) in an advanced stage of atresia with a thin layer of degenerated granulosa wall and a thickened thecal layer, which has been almost flattened by compression of neighbouring preovulatory follicles. The lower preovulatory follicle $(F)$ is in Stage Ib atresia. $\times 73$.

Fig. 12. A tortuous remnant of an old atretic follicle of which a thickened thecal layer (arrows) and a small remnant of the antrum are left. $\times 73$. 


\section{Results}

The total number of follicles, non-atretic and atretic, with a volume $\geqslant 100 \times 10^{5} \mu \mathrm{m}^{3}$ or a mean diameter of $\geqslant 275 \mu \mathrm{m}$, was constant during the 5-day cycle (Table 1). The low number at 10:00 h of pro-oestrus was not significantly different from the preceding or subsequent numbers. A decrease or an increase in the total number of non-atretic follicles was accompanied by an increase or decrease, respectively, in the total number of atretic follicles.

Table 1. Mean number ( \pm s.d.) of follicles per ovary in the various volume classes $\geqslant 100 \times 10^{5} \mu \mathrm{m}^{3}(=$ diam. of $\geqslant 275 \mu \mathrm{m}^{3}$ ) during the oestrous cycle of the rat

\begin{tabular}{|c|c|c|c|c|c|c|}
\hline \multirow{2}{*}{$\begin{array}{l}\text { Phase of } \\
\text { cycle } \\
\text { (no. of } \\
\text { animals) }\end{array}$} & \multicolumn{6}{|c|}{ Volume class $\left(10^{5} \mu \mathrm{m}^{3}\right)$} \\
\hline & $\stackrel{1}{100-199}$ & $\begin{array}{c}2 \\
200-349\end{array}$ & $\begin{array}{c}3 \\
350-499\end{array}$ & $\begin{array}{c}4 \\
500-999\end{array}$ & $\begin{array}{c}5 \\
1000\end{array}$ & $\begin{array}{l}\text { Total } \\
\text { no.* }\end{array}$ \\
\hline \multicolumn{7}{|l|}{ Dioestrus 1} \\
\hline $10: 00$ h (6) & $11 \cdot 7 \pm 3.9$ & $13 \cdot 8 \pm 2 \cdot 2$ & $4 \cdot 7 \pm 1 \cdot 5$ & $1 \cdot 3 \pm 1 \cdot 5$ & 0 & $\begin{array}{c}31.5 \pm 2 \cdot 7 \\
(15 \cdot 0 \pm 4 \cdot 6)\end{array}$ \\
\hline $17: 00 \mathrm{~h}(5)$ & $12 \cdot 4 \pm 2 \cdot 6$ & $12 \cdot 8 \pm 1 \cdot 9$ & $5 \cdot 6 \pm 1.9$ & $1 \cdot 0 \pm 0.7$ & 0 & $\begin{array}{c}31 \cdot 8 \pm 3.7 \\
(16.4 \pm 5 \cdot 2)\end{array}$ \\
\hline \multicolumn{7}{|l|}{ Dioestrus 2} \\
\hline $10: 00 \mathrm{~h}(6)$ & $9 \cdot 3 \pm 3 \cdot 1$ & $6 \cdot 0 \pm 3 \cdot 2 \dagger$ & $2 \cdot 8 \pm 2 \cdot 5$ & $5 \cdot 8 \pm 2 \cdot 4 \dagger$ & 0 & $\begin{array}{c}24 \cdot 0 \pm 8 \cdot 7 \\
(24 \cdot 8 \pm 3 \cdot 7)\end{array}$ \\
\hline $17: 00 \mathrm{~h}(5)$ & $8 \cdot 6 \pm 3 \cdot 4$ & $4 \cdot 0 \pm 3 \cdot 1$ & $2 \cdot 8 \pm 2 \cdot 5$ & $5 \cdot 0 \pm 1 \cdot 4$ & $0.2 \pm 0.4$ & $\begin{array}{c}20 \cdot 6 \pm 2 \cdot 9 \\
(22.6 \pm 4.8)\end{array}$ \\
\hline \multicolumn{7}{|l|}{ Dioestrus 3} \\
\hline $10: 00 \mathrm{~h}(6)$ & $6 \cdot 0 \pm 2 \cdot 1$ & $0 \cdot 3 \pm 0 \cdot 5$ & 0 & $2 \cdot 7 \pm 1 \cdot 4$ & $4 \cdot 0 \pm 2 \cdot 0 \dagger$ & $\begin{array}{c}13 \cdot 0 \pm 3 \cdot 5 \dagger \\
(31 \cdot 8 \pm 5 \cdot 0) \dagger\end{array}$ \\
\hline $17: 00 \mathrm{~h}(7)$ & $8 \cdot 4 \pm 3 \cdot 6$ & $1 \cdot 1 \pm 1 \cdot 5$ & $0 \cdot 3 \pm 0.5$ & $1.9 \pm 1 \cdot 3$ & $3.6 \pm 0.8$ & $\begin{array}{c}15 \cdot 3 \pm 5 \cdot 4 \\
(29 \cdot 7 \pm 4 \cdot 3)\end{array}$ \\
\hline \multicolumn{7}{|l|}{ Pro-oestrus } \\
\hline $10: 00 \mathrm{~h}(7)$ & $8 \cdot 4 \pm 4 \cdot 1$ & $0 \cdot 3 \pm 0 \cdot 5$ & 0 & $0.4 \pm 0.8 \dagger$ & $5 \cdot 4 \pm 2 \cdot 1$ & $\begin{array}{c}14 \cdot 6 \pm 3 \cdot 2 \\
(22 \cdot 3 \pm 9 \cdot 3)\end{array}$ \\
\hline $17: 00 \mathrm{~h}(5)$ & $7 \cdot 8 \pm 1 \cdot 9$ & $0.4 \pm 0.5$ & 0 & $0.4 \pm 0.5$ & $4.4 \pm 1.9$ & $\begin{array}{c}13 \cdot 0 \pm 1 \cdot 0 \\
(28 \cdot 2 \pm 6 \cdot 6)\end{array}$ \\
\hline \multicolumn{7}{|l|}{ Oestrus } \\
\hline $10: 00$ h (6) & $20 \cdot 2 \pm 3 \cdot 9 \dagger$ & $7 \cdot 8 \pm 1 \cdot 3 \dagger$ & $0 \cdot 3 \pm 0 \cdot 5$ & 0 & 0 & $\begin{array}{c}28.3 \pm 4.5 \dagger \\
(19.3 \pm 5.7) \dagger\end{array}$ \\
\hline $10: 00 \mathrm{~h}(5)$ & $19 \cdot 8 \pm 3 \cdot 8 \ddagger$ & $13 \cdot 4 \pm 4 \cdot 5$ & $1 \cdot 2 \pm 1 \cdot 3 \ddagger$ & $0 \cdot 2 \pm 0 \cdot 4$ & 0 & $\begin{array}{c}34 \cdot 6 \pm 3 \cdot 0 \\
(12 \cdot 0 \pm 3 \cdot 9)\end{array}$ \\
\hline
\end{tabular}

* Total no. of atretic follicles in parentheses.

+ Significantly different from previous number, $P<0.05$ (Wilcoxon two-sample test).

$\ddagger$ Significantly different from value on dioestrus $1,10: 00 \mathrm{~h}, P<0.05$ (Wilcoxon two-sample test).

\section{Follicular atresia}

Percentages were used for comparison of the data, rather than absolute numbers because of the constant size of the follicle population. The percentage of atretic follicles in the follicle population $\geqslant 100 \times 10^{5} \mu \mathrm{m}^{3}$ (diam. $\geqslant 275 \mu \mathrm{m}$ ) increased from $\sim 30 \%$ at $10: 00 \mathrm{~h}$ of dioestrus 1 to about $70 \%$ at $10: 00 \mathrm{~h}$ of dioestrus 3 (Text-fig. 1). Values did not change significantly until late pro-oestrus, when they fell to reach at 17:00 h of oestrus a level similar to that of early dioestrus 1 .

The distributions of the various stages of atresia in the follicle population are shown in Text-fig. 2. The percentage of atretic follicles in the earliest stage of atresia (Ia) was about $15 \%$ of the whole population of follicles $\geqslant 100 \times 10^{5} \mu \mathrm{m}^{3}$ at early dioestrus 1 , decreased at late dioestrus 2 , increased again in the morning of dioestrus 3 , continuously dropped to $5 \%$ at $10: 00 \mathrm{~h}$ of pro-oestrus and 


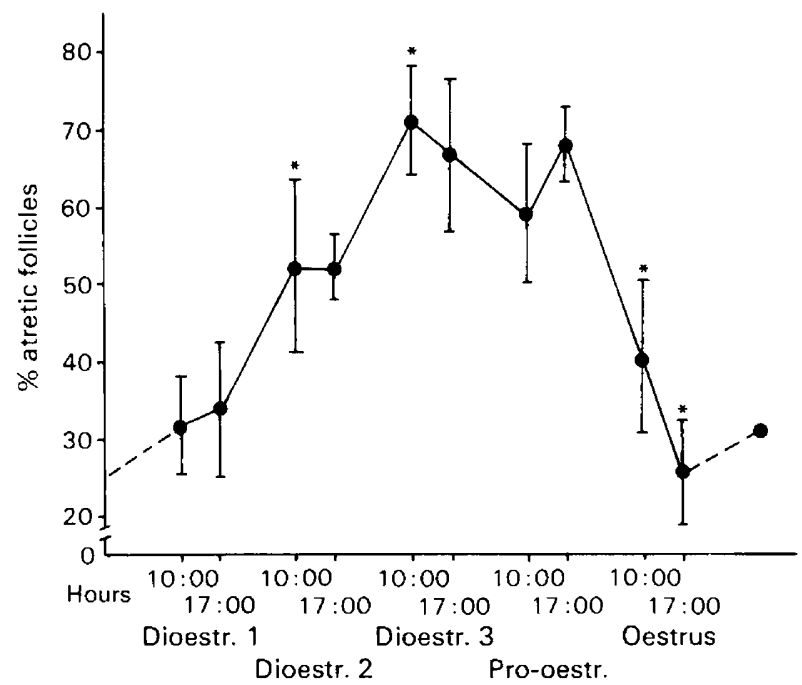

Text-fig. 1. Percentages of atretic follicles in the follicle population $\geqslant 100 \times 10^{5} \mu \mathrm{m}^{3}$ during the oestrous cycle. Values are the means \pm s.d. (vertical bars) in one ovary from 5-7 animals. ${ }^{*} P \leqslant 0.02$ as compared to previous value.

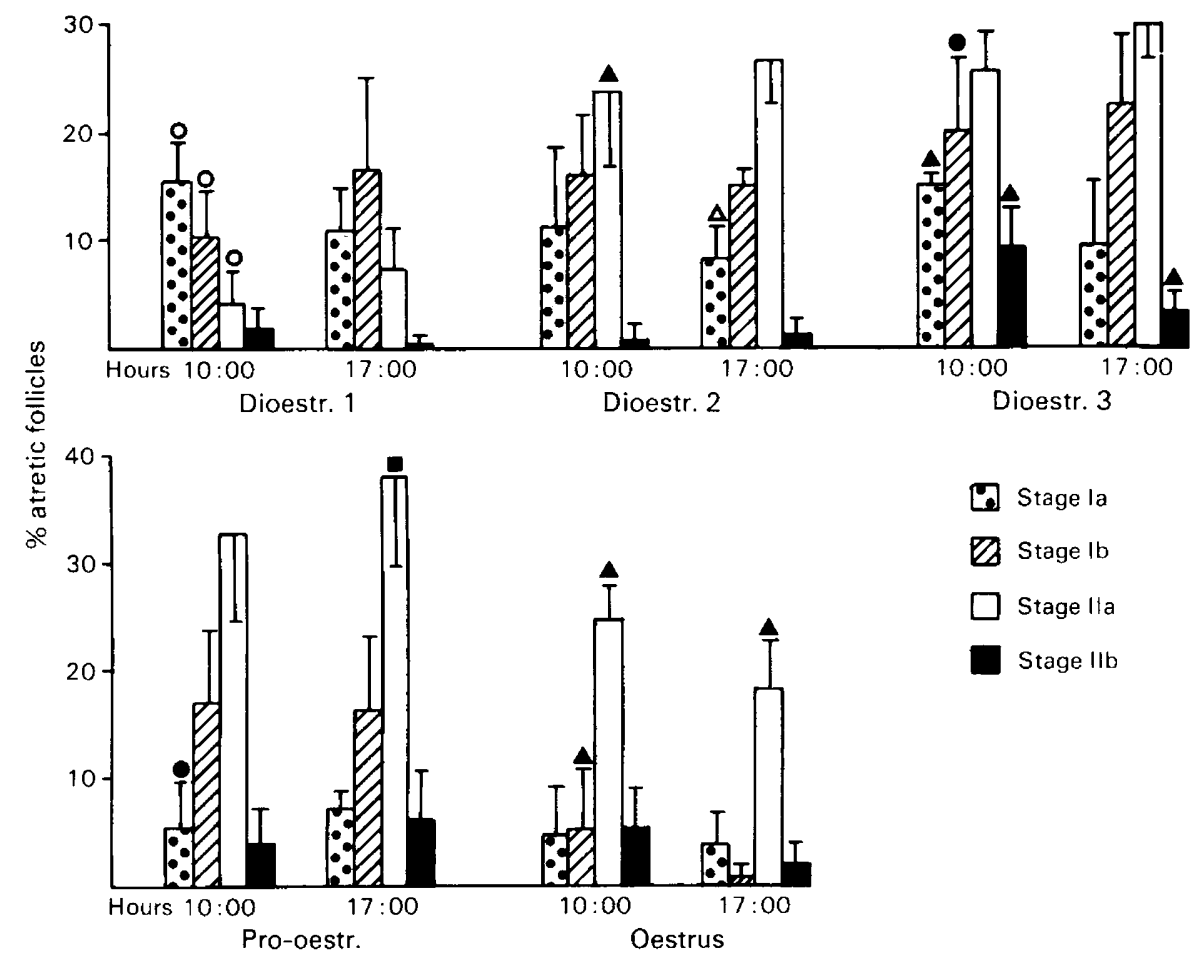

Text-fig. 2. Distribution of the various stages of atresia in percentages of the follicle population $\geqslant 100 \times 10^{5} \mu \mathrm{m}^{3}$ during the oestrous cycle. Values are mean $\pm \mathbf{s . d}$. $\Delta$, Significantly different from value for that stage at immediately preceding time of the cycle;, significantly different from value $24 \mathrm{~h}$ earlier; $\square$, significantly different from value on dioestrus $3,10: 00 \mathrm{~h} ; 0$, significantly different from value on oestrus, $17: 00 \mathrm{~h} ; \triangle$, significantly different from value on dioestrus $1,10: 00 \mathrm{~h}$. 
remained at that level during late pro-oestrus and the day of oestrus. The percentage of follicles in Stage $\mathrm{Ib}$ was about $10 \%$ at early dioestrus 1 , seemed to increase at late dioestrus 1 and early dioestrus 2 and was significantly higher after $24 \mathrm{~h}$ at early dioestrus 3 , but decreased to about $5 \%$ at $10: 00 \mathrm{~h}$ of oestrus. The percentage of follicles in Stage IIa was $<5 \%$ at early dioestrus, increased at $10: 00 \mathrm{~h}$ of dioestrus 2 , remained constant at dioestrus 3, but increased further until $17: 00 \mathrm{~h}$ of prooestrus, after which it decreased continuously. The percentage of atretic follicles in Stage IIb was low until an increase at $10: 00 \mathrm{~h}$ of dioestrus 3 , but had decreased again by 17:00 $\mathrm{h}$ on the same day, after which it remained at about $5 \%$ until late oestrus when a further decrease was indicated.

The mean numbers of atretic follicles in the various stages are shown in Table 2. If Stage Ia is taken as the indicator for atresia, the atretic rate in the follicle population $\geqslant 100 \times 10^{5} \mu \mathrm{m}^{3}$ from which all the later stages of atresia are excluded, appeared different from that shown in Text-fig. 1 (see Text-fig. 3). Two consecutive increments were found in the proportion of atretic follicles, i.e. from $17: 00 \mathrm{~h}$ of oestrus to $10: 00 \mathrm{~h}$ of dioestrus 1 amounting to $20 \%$, followed by a greater increase amounting to $35 \%$ at $10: 00 \mathrm{~h}$ of dioestrus 3 . After dioestrus 3 values decreased considerably until 17:00 h of oestrus with an insignificant rise during pro-oestrus.

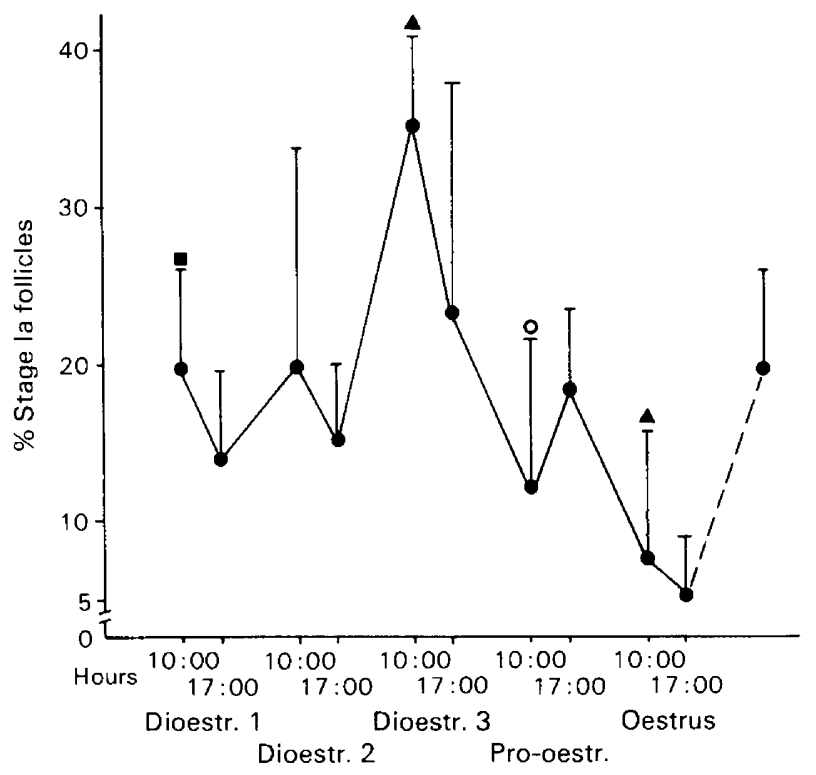

Text-fig. 3. Atretic waves during the cycle, expressed by the percentages of Stage Ia atretic follicles in the follicle population $\geqslant 100 \times 10^{5} \mu \mathrm{m}^{3}$, from which all other follicles in the advanced stages of atresia are excluded. $\boldsymbol{\Delta}$. Significantly different from previous value; $O$, significantly different from value $24 \mathrm{~h}$ earlier; $\boldsymbol{a}$, significantly different from values at oestrus. Values are mean \pm s.d.

The rate of atresia in the various volume classes of follicles during the oestrous cycle when Stage Ia only is used as the indicator of atresia is shown in Text-fig. 4. Because of the small individual numbers of follicles the data of percentages were obtained from the pooled numbers of non-atretic follicles in Stage Ia in the ovaries of the animals in the same phase of the cycle used in Table 1. No standard deviations can therefore be shown. Class 1 follicles had an atretic rate of $15-20 \%$ which increased to about $40 \%$ at $10: 00 \mathrm{~h}$ of dioestrus 3 and was lowest during oestrus $(5-7 \%)$. For Class 2 follicles the rate was about $20 \%$ during dioestrus 1 and $2,90 \%$ at $10: 00 \mathrm{~h}$ of dioestrus 3 and then decreased to the same level as the Class 1 follicles at oestrus. Class 3 follicles had a low incidence of atresia $(5 \%)$ at dioestrus $1,26-30 \%$ atresia at dioestrus 2 and $70-100 \%$ at the day of dioestrus 3 . 
Table 2. Mean number ( \pm s.d.) of atretic follicles in the various stages of atresia per ovary during the oestrous cycle of the rat

\begin{tabular}{|c|c|c|c|c|c|c|c|c|c|c|}
\hline \multirow[b]{2}{*}{ Stage } & \multicolumn{2}{|c|}{ Dioestrus I } & \multicolumn{2}{|c|}{ Dioestrus 2} & \multicolumn{2}{|c|}{ Dioestrus 3} & \multicolumn{2}{|c|}{ Pro-oestrus } & \multicolumn{2}{|c|}{ Oestrus } \\
\hline & $\begin{array}{l}10: 00 h \\
(N=6)\end{array}$ & $\begin{array}{l}17: 00 h \\
(N=5)\end{array}$ & $\begin{array}{l}10: 00 \mathrm{~h} \\
(\mathrm{~N}=6)\end{array}$ & $\begin{array}{l}17: 00 h \\
(N=5)\end{array}$ & $\begin{array}{l}10: 00 h \\
(N=6)\end{array}$ & $\begin{array}{l}17: 00 \mathrm{~h} \\
(\mathrm{~N}=7)\end{array}$ & $\begin{array}{l}10: 00 \mathrm{~h} \\
(\mathrm{~N}=7)\end{array}$ & $\begin{array}{l}17: 00 \mathrm{~h} \\
(\mathrm{~N}=5)\end{array}$ & $\begin{array}{l}10: 00 \mathrm{~h} \\
(\mathrm{~N}=6)\end{array}$ & $\begin{array}{l}17: 00 \mathrm{~h} \\
(\mathrm{~N}=5)\end{array}$ \\
\hline Ia & $7 \cdot 3 \pm 2 \cdot 4$ & $5 \cdot 2 \pm 2 \cdot 4$ & $5 \cdot 0 \pm 1 \cdot 8$ & $3.8 \pm 1.9$ & $6.8 \pm 0.8$ & $4.4 \pm 2.8$ & $2 \cdot 1 \pm 2 \cdot 0$ & & $2 \cdot 3 \pm 2 \cdot 4$ & $2 \cdot 0 \pm 1 \cdot 6$ \\
\hline Ib & $4 \cdot 8 \pm 2 \cdot 1$ & $7 \cdot 4 \pm 3 \cdot 2$ & $7 \cdot 7 \pm 2 \cdot 3$ & $6.6 \pm 1 \cdot 1$ & $9 \cdot 3 \pm 2 \cdot 5$ & $10 \cdot 1 \pm 2.5$ & $6.6 \pm 4.0$ & $7.0 \pm 3.6$ & $2 \cdot 5 \pm 2 \cdot 5$ & $0.4 \pm 0.5$ \\
\hline IIa & $2 \cdot 0 \pm 1 \cdot 5$ & $3 \cdot 6 \pm 2.7$ & $11 \cdot 7 \pm 4 \cdot 2$ & $11 \cdot 6 \pm 2.8$ & $11 \cdot 7 \pm 2 \cdot 8$ & $13 \cdot 6 \pm 2 \cdot 0$ & $12 \cdot 0 \pm 4 \cdot 2$ & $15.4 \pm 1.9$ & $11 \cdot 8 \pm 1 \cdot 8$ & $8 \cdot 6 \pm 2 \cdot 4$ \\
\hline IIb & $0.8 \pm 1 \cdot 0$ & $0.2 \pm 0.4$ & $0.5 \pm 0.8$ & $0.6 \pm 0.5$ & $4 \cdot 0 \pm 2 \cdot 1$ & $1.6 \pm 0.8$ & $1.6 \pm 1.5$ & $2 \cdot 8 \pm 2 \cdot 6$ & $2 \cdot 7 \pm 2 \cdot 1$ & $1 \cdot 0 \pm 1 \cdot 0$ \\
\hline
\end{tabular}

Class 4 follicles were present only in considerable number from 10:00 h of dioestrus 2 with an atretic rate of $0-5 \%$ which increased to $15-20 \%$ at dioestrus 3 . No atretic follicles were found at prooestrus and oestrus. The incidence of atresia in Class 5 follicles which emerged in considerable number at $10: 00 \mathrm{~h}$ of dioestrus 3 , was $<5 \%$ and remained low during pro-oestrus. The non-atretic follicles were presumably the ones destined to ovulate since no follicles were found at early oestrus.

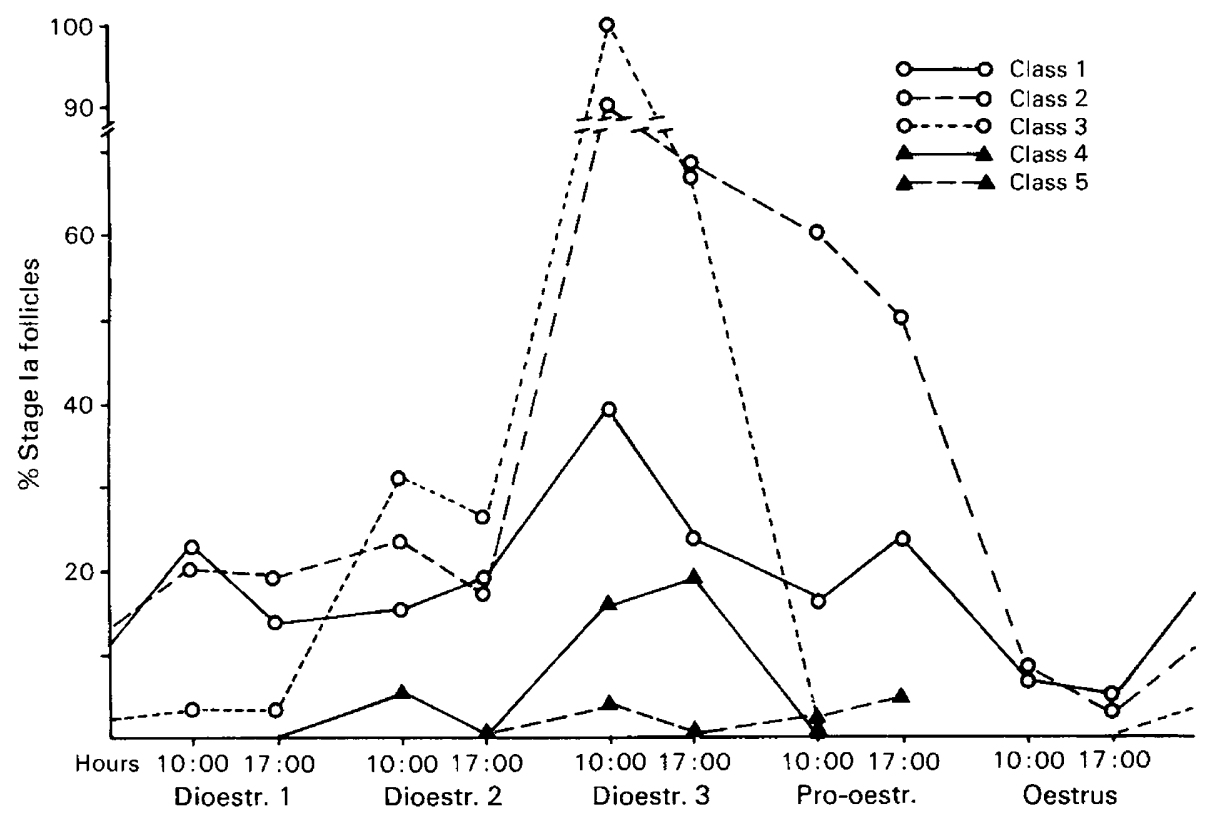

Text-fig. 4. Rate of atresia in the various volume classes of follicles during the cycle, expressed as the percentages of Stage Ia atretic follicles in the follicle population (see Text-fig. 3). Data were obtained from the pooled numbers of atretic (Ia) and non-atretic follicles in one ovary of the animals in the same phases of the cycle as used in Table 1.

\section{Histological observations}

Follicles in the advanced stages of atresia, Stages IIa and IIb, showed many deformities especially during oestrus and dioestrus 1 ( $\mathrm{Pl} .2$, Figs $8,10 \& 11)$, probably due to loss of tone of the wall and to compression by surrounding structures. Some were discarded because they were either not measurable since they had lost the reference point (oocyte), had fallen into a volume class smaller than $100 \times 10^{5} \mu \mathrm{m}^{3}$, or had remained only as remnants of follicles (Pl. 2, Figs $9 \& 12$ ). Atretic follicles in Stage IIb with an ovoid or spherical form (Pl. 2, Fig. 7: lower follicle) and an apparently stable wall were not numerous; most of them belonged in volume class 1 . 


\section{Follicular growth}

No remarkable changes in follicular growth were found at 10:00 h and at 17:00 h on each day of the oestrous cycle (Table 1). At pro-oestrus non-atretic follicles were present in considerable numbers only in two volume classes in the ovary: about 5 follicles in Class 5 , and 7-8 follicles in Class 1. At 10:00 h of oestrus, 20 follicles emerged in Class 1 and about 8 follicles grew into Class 2 into which more follicles seemed to grow at 17:00 h of oestrus. At early dioestrus 1 a decrease in number of Class 1 follicles and an increase of Class 3 follicles were recorded. Few follicles had grown into the ovulable size, Class 4 (Welschen \& Rutte, 1971). This situation did not change at late dioestrus 1. At dioestrus 2, a significant decrease in the number of Class 2 follicles and an increase in the number of Class 4 follicles were observed as compared to the numbers at dioestrus 1 . Indications of a decrease were noted in Class 1 and Class 3 follicles. At 10:00 h of dioestrus 3, Class 1 follicles remained low in number, differing significantly only from those of dioestrus 1 . Almost no healthy follicles in the Classes 2 and 3 were found. More follicles were observed in the largest volume class; $2-3$ follicles were still present in Class 4 and remained until late dioestrus 3 . Almost no follicles were present in Class 4 at pro-oestrus.

\section{Discussion}

The number of non-atretic and atretic follicles with a volume class of $\geqslant 100 \times 10^{5} \mu \mathrm{m}^{3}$ or a mean diameter of $\geqslant 275 \mu \mathrm{m}$ recorded during the whole oestrous cycle was constant. It could not be due to coincidence, since the study involved 10 groups of rats. This follicle population consists of mostly antral follicles which form an important part of the ovarian tissue. Their growth and disappearance, which are continuous processes, could possibly be related to availability of space in the ovarian interstitium which also contains corpora lutea, blood vessels and smaller follicles. Although the division in the various volume classes is arbitrary in the present study, it provides a useful method for the morphometric analysis of follicular growth and atresia. The classification of atretic follicles in 4 stages also seems to provide an indirect method for analysing the frequency of sequential stages in a part of the atretic process, since it is difficult to label and follow individual follicles for an extended period of time (Byskov, 1978). The high percentage of atretic follicles at dioestrus 3 and at pro-oestrus (Text-fig. 1), including many follicles in the advanced stages of atresia Ib, IIa and IIb, could not be used as an indicator for the rate of atresia at a certain cycle phase, since more than a half day has elapsed before these stages are reached.

The high number of follicles showing the conspicuous morphological characteristics of these late stages of atresia may lead to the wrong conclusion that atresia is greatest during the periods in which they were observed. Atretic follicles in Stage IIa (Text-fig. 2: 10:00 h of dioestrus 2) which must have developed from those in Stage Ia through Stage Ib, needed at least $24 \mathrm{~h}$ to reach that stage, and for some of the follicles, another $24 \mathrm{~h}$ to reach Stage IIb for which the percentage increased for the first time at 10:00 h of dioestrus 3. Since the number of follicles in Stage IIa remained constant during dioestrus 2 and dioestrus 3, the atretic process seemed to slow down during that period, resulting in accumulation of follicles in Stage Ib as already apparent at early dioestrus 3. The further increase of atretic follicles in Stage IIa at $17: 00 \mathrm{~h}$ of pro-oestrus could be due to accumulation of follicles in that stage by continuous influx from the previous Stage Ib. The increase in follicles at Stage Ia at dioestrus 3 suggests a new wave of atresia.

Not all atretic follicles in Stage IIa seemed to reach Stage IIb, since the quick decrease in number of follicles of this type after 17:00 h of pro-oestrus was not followed by an increase in number of follicles in Stage IIb. Since Stage IIb follicles seemed to be unstable, as deduced from the rapid changes in number at dioestrus 3, a quick transformation to unrecognizable or unmeasurable forms could not be excluded. This also explains the marked decrease in number of atretic follicles in Stage IIa after late pro-oestrus when compression could have taken place due to the rapid distension of preovulatory follicles (Pl. 2, Fig. 10) and the development of interstitial 
oedema (Osman, 1975), and to growing young corpora lutea at oestrus. Only those follicles with a stable wall, seemingly derived from Class 1 follicles (Pl. 2, Fig. 7), could be classified and counted.

The use of Stage Ia as an indicator for the rate of atresia seems to be justified, since follicles in the advanced stages do not indicate the actual time in which atresia is initiated or represent the volume class of follicles to which they actually belonged because of deformities (see 'Results: histological observations'). The presence of two increments in the atretic rate (Text-fig. 3) means that the ovarian follicles when entering the growth phase are affected by two consecutive waves of atresia during the oestrous cycle; this is also seen in the reduction in number of non-atretic follicles at early dioestrus 1 and early dioestrus 3 (Table 1). At dioestrus 1 it was mainly Class 1 follicles that had to loose about 8 follicles, but at 10:00 h of dioestrus 3 all three smaller volume classes contained fewer follicles. The time for follicles to move between Stages Ia and Ib seems to be $<0.5$ days but if both stages were used together, a profile of the atretic rate similar to that in Text-fig. 3 was obtained.

It seems evident from the present study that only those follicles that have grown into volume Class 4 at dioestrus 3 and into Class 5 at pro-oestrus have escaped atresia and will be the ones that ovulate, whereas the follicles that are still in Classes 2 and 3 are all destined to degenerate (Table 1). A pool of about 7-8 follicles is maintained in Class 1 , probably by turnover of new follicles since this class of follicles is continuously affected by atresia (Text-fig. 4). This pool of follicles will probably grow into Class 2 follicles after the gonadotrophin surge which also induces a new cohort of antral follicles in Class 1 at early oestrus. Since the follicles in the pool are derived from the preceding cycle, they are older than the newcomers, will grow faster, reach the larger volume classes least affected by atresia at dioestrus 3 and ovulate. If this assumption is true the antral follicles destined to ovulate are already present in the preceding cycle and need therefore more than one cycle to complete their growth and ovulate. This is in agreement with the findings in mice that the transit time required for type 5a follicles to grow to ovulatory size needs two oestrous cycles (Pedersen, 1970; Numazawa \& Kawashima, 1982); the type 5a follicles of mice could perhaps be compared to the bigger Class 1 follicles of the rat, since follicular size is closely related to body size (Parkes, 1931).

I thank Mrs C. Lieuwma-Noordanus for excellent histo-technical work and Mrs E. Klink for typing the manuscript.

\section{References}

Bill, C.H. \& Greenwald, G.S. (1981) Acute gonadotropin deprivation. I. A model for the study of follicular atresia. Biol. Reprod. 24, 913-921.

Boling, J.L., Blandau, R.J., Soderwall, A.L. \& Young, W.C. (1941) The growth of the Graafian follicle and the time of ovulation in the albino rat. Anat. Rec. 79 , 313-331.

Braw, R.H. \& Tsafriri, A. (1980a) Follicles explanted from pentobarbitone-treated rats provide a model of atresia. J. Reprod. Fert. 59, 259-265.

Braw, R.H., Bar-Ami, S. \& Tsafriri, A. (1981) Effect of hypophysectomy on atresia of rat preovulatory follicles. Biol. Reprod. 25, 989-996.

Burkl, W. \& Kellner, G. (1956) Das Wachstum der Follikel und die Reifung der Eizellen in den verschiedenen Zyclusphasen bei der Ratte. Acta anat. 27, 309-323.

Byskov, A.G.S. (1974) Cell kinetic studies of follicular atresia in the mouse ovary. J. Reprod. Fert. 37, 277285 .
Byskov, A.G.S. (1978) Follicular atresia. In The Vertebrate Ovary, Ch. 15, pp. 533-562. Ed. R. E. Jones. Plenum Press, New York.

Deane, H.W. (1952) Histochemical observations on the ovary and oviduct of the albino rat during the estrous cycle. Am. J. Anat. 91, 363-414.

Foote, W.D. \& Thibault, C. (1969) Recherches expérimentales sur la maturation in vitro des ovocytes de truie et de veau. Annls Biol. anim. Biochim. Biophys. 9, 329-349.

Gondos, B. (1982) Ultrastructure of follicular atresia in the rat. Gamete Res. 5, 199-206.

Hirshfield, A.N. (1983) Compensatory ovarian hypertrophy in the long-term hemicastrate rat: size distribution of growing and atretic follicles. Biol. Reprod. 28, 271-278.

Hirshfield, A.N. \& Midgley, A.R., Jr (1978) Morphometric analysis of follicular development in the rat. Biol. Reprod. 19, 597-605. 
Lane, C.E. \& Davis, F.R. (1939) The ovary of the adult rat. I. Changes in growth of the follicle and in volume and mitotic activity of the granulosa and theca during the oestrous cycle. Anat. Rec. 73, 429-442.

Mand, A. \& Zuckerman, S. (1950) The numbers of normal and atretic ova in the mature rat. J. Endocr. 6, 426-435.

Mandl, A. \& Zuckerman, S. (1952) Cyclical changes in the number of medium and large follicles in the adult rat ovary. J. Endocr. 8, 341-346.

Numazawa, A. \& Kawashima, S. (1982) Morphometric studies on ovarian follicles and corpora lutea during the oestrous cycle in the mouse. J. Reprod. Fert. 64, 275-283.

Osman, P. (1975) Preovulatory changes in the ovaries during first spontaneous pro-oestrus in the rat. $J$. Endocr. 67, 259-265.

Parkes, A.S. (1931) The reproductive processes of certain mammals. II. The size of the Graafian follicle at ovulation. Proc. R. Soc. B 109, 185-196.
Pedersen, T. (1970) Follicle kinetics in the ovary of cyclic mouse. Acta endocr., Copenh. 64, 304-323.

Terranova, P.F. (1980) Effects of phenobarbital-induced ovulatory delay on the follicular population and serum levels of steroids and gonadotrophins in the hamster: a model for atresia. Biol. Reprod. 23, 92-99.

Uilenbroek, J.Th.J., Woutersen, P.J.A. \& van der Schoot, P. (1980) Atresia of preovulatory follicles: gonadotropin binding and steroidogenic activity. Biol. Reprod. 23, 219-229.

Welschen, R. (1973) Amounts of gonadotrophins required for normal follicular growth in hypophysectomized adult rats. Acta endocr., Copenh. 72, 137-155.

Welschen, R. \& Rutte, M. (1971) Ovulation in adult rats after treatment with pregnant mare serum gonadotrophin during oestrus. Acta endocr., Copenh. 68, 4149.

Winer, B.J. (1971) Statistical Principles in Experimental Design. McGraw-Hill Book Company, New York.

Received 23 May 1984 